\title{
Study on Simulation of Biomass Gasification for Syngas Production in a Fixed Bed Reactor
}

\author{
Bedewi Bilal ${ }^{1}$, M. RaviKumar ${ }^{2}$
}

1, 2 Department of Chemical Engineering, College of Engineering and Technology, Samara University, Samara, Afar, Ethiopia

\begin{abstract}
This study was focusing on the simulation of the biomass (coffee bean husk and rice husk) gasification process based on the kinetics of the gasifier and to investigate the produced syngas composition. The ASPEN PLUS simulator was used to investigate the effect of operating parameters on composition of product gas. The gasification process usually begins with the drying process, and then followed by pyrolysis. The pyrolysis process leads to breaking down of the biomass into solid matter, gaseous mixture (mainly $\mathrm{CO}_{2}, \mathrm{CO}, \mathrm{CH}_{4}$ and $\mathrm{H}_{2}$ ) and liquid matter. The main focus on biomass gasification process is to efficiently convert the entire char constituent into gaseous product of the syngas by using either steam or $\mathrm{CO}_{2}$. The simulations include; gasification temperature, pressure, reactor volume, Equivalence ratio and moisture content have been investigated. From the result of sensitivity analysis increase the temperature the production of $\mathrm{H}_{2}$ and $\mathrm{CO}$ and the increase of moisture content of the biomass the lower heating value of the producer gas decrease. Based on the obtained result the maximum lower heating value of syngas was obtained at the gasification temperature of $800^{\circ} \mathrm{C}$, steam to biomass ratio of 0.1 , pressure of 1 bar, 0.05 of moisture content and $0.02 \mathrm{~m}^{3}$ of reactor volume.
\end{abstract}

Keywords: Fixed bed gasifier, biomass, equivalence ratio, ASPEN PLUS

\section{INTRODUCTION}

Biomass gasification is one of the most popular processes which produce energy in the form of syngas and as the same time it reduces the environmental hazards of raw biomass. In addition, being a renewable energy source, biomass gasification also helps reduction of net greenhouse gas emission and moderation of global warming [3]. Gasification is a thermochemical process that converts organic or fossil based carbonaceous material into a combustible gas by react the material under a certain range of temperature with a controlled/starved amount of air/oxygen often with a combination of steam. Biomass as a product of photosynthesis is one of the most abundant renewable resource that can be used for sustainable production of syngas (a mixture of $\mathrm{CO}$ and H2) [4].The gasification process requires some gasifying agent that provides oxygen for the formation of $\mathrm{CO}$ from solid carbon in the fuel. The gasifying agents include air, oxygen, steam and $\mathrm{CO} 2$ [5]. The gasification process usually begins with drying sub-zone and then followed by pyrolysis. The pyrolysis process leads the breaking down of the biomass into solid matter (charcoal), gaseous mixture (mainly $\mathrm{CO} 2, \mathrm{CO}, \mathrm{CH} 4$ and $\mathrm{H} 2$ ) and liquid matter (tar). The main focus in biomass gasification process is to efficiently convert the entire char constituent into gaseous product of the syngas by using either steam or CO2 [6].Biomass gasifiers are complex facilities, which make it difficult to investigate their various operating conditions. The characteristics of biomass greatly influence the performance of a biomass gasifier. A proper understanding of the physical and the chemical properties of biomass feedstock is essential for the design and operation of a 
biomass gasifier to be reliable. There are numerous models for biomass gasification has been developed. These models can be categorized into thermodynamic equilibrium models and kinetic models. The thermodynamic equilibrium models, also known as zero-dimensional models, are widely used among researchers to predict the composition of the produced syngas and the equilibrium temperature by assuming that the chemical reactions reach equilibrium. However, these models cannot provide highly accurate results and also cannot provide the concentration or temperature profiles inside the reactor. Kinetic models provide essential information on kinetic mechanisms to describe the chemical reactions involved in the biomass gasification, which is crucial in designing, evaluating and improving gasifiers. These models are based on the chemical reaction rates and are able to predict both overall and profiles of producer gas yield and compositions with time and location within the gasifier. However, as the models involve a number of reactions and transfer process, the models are computationally intensive [7].Gasification is expected to be the future method of producing an energy carrier, and the production of syngas from biomass or waste would require gasification as an essential part of the overall process. Current Gasifiers can be classified into two types: fixed-bed gasifiers and fluidized-bed gasifier [1]. Fluidized bed gasification is often adopted for larger capacity of biomass feedstock. Fluidized bed gasification is more complicated in constructing and operating, and also requires a higher investment. For this study kinetic simulation of fixed bed gasification is chosen because of the suitability for any type of biomass and the lower investment cost requirements. Fixed bed gasification also has the advantage of a small amount of fly ash, and the syngas from biomass gasification can be used in various areas as clean energy [8].

\section{METHODS AND MATERIAL}

\section{Biomass feedstock characterization:}

The raw materials used in this study are agricultural residues (coffee bean husk and rice husk) locally produced in Ethiopia's farmlands. These materials were collected from farmlands and local community around Bahir Dar, Ethiopia. The chemistry of biomass gasification is similar to that of coal gasification and the general chemical formula used for the coffee bean husk and the rice husk was $\mathrm{CH} 1.76 \mathrm{O} 0.78 \mathrm{~N} \quad 0.03$ and $\mathrm{CH} 1.64 \mathrm{O} 0.95 \mathrm{~N} \quad 0.005$ respectively. Therefore, stoichiometric air required for complete oxidation of coffee bean husk and rice husk can be calculated from the reaction and $4.58 \mathrm{~kg}$ and $4.26 \mathrm{~kg}$ of air was required for complete combustion of $1.5 \mathrm{~kg}$ of coffee bean husk and rice husk respectively.

\section{Proximate Analysis:}

A sample of each biomass is taken randomly and tested for proximate analysis to get the comprehensive details of biomass feed. Proximate analysis, which is a standardized procedure that gives an idea of the bulk components that make up a fuel, was done to determine the average of the percentage volatile matter content, percentage ash content, moisture content and percentage content of fixed carbon of the biomass obtained by using ASTM E872, ASTM D1102 and ASTM respectively.[7]

\section{Moisture Content (MC):}

The percentage moisture content (PMC) was found by weighing of the biomass sample (B0) and oven drying it at the temperature of $105^{\circ} \mathrm{C}$ until constant weight of the sample (B1) was obtained. The loss in weight resulted in the amount of moisture present and sample left in the crucible are total solids present in the sample. The change in weight (B2) was then used to determine the sample's percentage moisture content by using the following equation:

$$
\mathrm{PM}=\mathrm{B} 2 / \mathrm{B} 0 \times 100
$$




\section{Volatile Matter (VM):}

The percentage volatile matter (PVM) was determined by pulverizing the oven dried biomass sample in a crucible and placing it at $550^{\circ} \mathrm{C}$ for 10 minutes in a Box type resistance furnace Model BK $5-12$ GJ until a constant weight was obtained and weighed after cooling in desiccators.

The PVM was then calculated by using the following equation

$$
P M C=\frac{\mathrm{B}_{0}-\mathrm{B}_{1}}{\mathrm{~B}_{0}} \times 100
$$

\section{Ash Content (AC):}

The percentage ash content (PAC) was also determined by heating oven dried biomass samples in open silica crucible at $550^{\circ} \mathrm{C}$ for minimum of 4 hours in Box type resistance furnace Model BK - 5 - 12GJ and weighed after cooling in a desiccator to obtain the weight of ash $(\mathrm{C})$.

$$
\mathrm{PAC}=\frac{\mathrm{C}}{\mathrm{B}_{0}} \times 100
$$

\section{Fixed Carbon :}

The percentage fixed carbon (PFC) was computed by subtracting the sum of PVM and PAC from 100 as shown in the following equation:

Fixed Carbon=100 \%-(PAC+PMC+PVM)

\section{Ultimate Analysis :}

This analysis is important for determining the elemental composition ( $\mathrm{C}, \mathrm{N}, \mathrm{H}, \mathrm{S}, \mathrm{O}$ etc.) of the biomass fuels and the empirical formula of biomass as $\mathrm{C} n \mathrm{H} m \mathrm{O} x \mathrm{~N} y$ in order to establish stoichiometric equation for complete combustion of biomass and equivalence ratio for the gasification reaction. It was carried out by using EA 1112 Flash CHNS/Oanalyzer. For the determination of elemental analysis of the biomass, the following condition was carried out, Carrier gas flow rate of $120 \mathrm{ml} / \mathrm{min}$, reference flow rate $100 \mathrm{ml} / \mathrm{min}$, oxygen flow rate $250 \mathrm{ml} / \mathrm{min}$; furnace temperature of $900^{\circ} \mathrm{C}$ and oven temperature of $75^{\circ} \mathrm{C}$.

\section{Process Simulation Model Development:}

In the area of process modelling and simulation, there are a number of processes modelling software packages available to develop computational model of gasification process and to perform simulation and validation studies. From those types of software packages researchers and professionals use Aspen Plus, Computational Fluid Dynamics (CFD, composed of GAMBIT and FLUENT), Chem-CAD and Mat Lab to develop and optimize the gasification models. From the above mentioned software packages, Aspen Plus is one of the sophisticated processes modeling computer software packages which is familiar to many users and has proven its capacity for gasification model development and simulation [1]. It is a market leading comprehensive chemical process modeling tool, used by the world's leading chemistry organization and related industries. It originated from a joint called Advanced project System for Process Engineering (ASPEN) which is started by the Massachusetts institute of Technology (MIT) and the US Department of engineering in the 1970's and finished in 1981. Aspen Tech was found in the same year and ASPEN project was commercialized Aspen Tech called Aspen Plus[8]Aspen Plus is used in the industrial chemical process modeling, simulation, optimization, sensitivity analysis and economic evaluation. It provides a comprehensive physical property models and the library of unit operation models, fast and reliable process simulation functions, and advanced calculation method. With the physical property database and the operation models provided by Aspen Plus, engineers are able to simulate actual plant behavior effectively and accurately thereby improve the productivity and reduce the costs.[9] Due to its reliability and precise outcomes in process modeling and simulation, Aspen Plus was used in this 
study to develop and simulate a fixed bed gasification process for coffee bean husk and rice husk as feed stocks. The simulations process was based on the mass-energy balance and chemical kinetics for the overall process. It comprises several databases containing physical, chemical and thermodynamic data for a wide variety of chemical compounds, as well as a selection of kinetic models required for the accurate simulation of any given system[10].

In Aspen Plus, there is no particular gasifier model ready for use, therefore to model a fixed bed gasifier, it is necessary to separate the whole process into different blocks. The process and the main unit operations involved in the gasification of fixed bed gasifier were drying, pyrolysis (decomposition), gasification and combustion) were simulated by using the reactors RStoic, RYield and RCSTR. As the simulation in this study is based on kinetic modeling, the reaction kinetic parameters are considered. The following assumptions were considered in modeling the gasification process. Process is isothermal and steady state, particles are spherical and are not affected in course of the reaction, the simulation is carried with power-law kinetics, the residence time for reactants is sufficiently high to reach chemical equilibrium and liquid modeling is considered rather than solid modeling for biomass due to unavailability of certain parameters. The gasification reactions which play a great role for the production of syngas from the pyrolysis sub-zone to combustion sub-zone are the following.

Oxidation reactions:

$$
\begin{aligned}
\mathrm{C}+0.5 \mathrm{O}_{2} & \rightarrow \mathrm{CO} & \Delta \mathrm{H}=+123.1 \mathrm{KJ} / \mathrm{mol}----(5) \\
\mathrm{C}+\mathrm{O}_{2} & \rightarrow \mathrm{CO}_{2} & \Delta \mathrm{H}=+393.8 \mathrm{KJ} / \mathrm{mol}--(6) \\
\mathrm{H}_{2}+0.5 \mathrm{O}_{2} & \rightarrow \mathrm{H}_{2} \mathrm{O} & \Delta \mathrm{H}=+242 \mathrm{KJ} / \mathrm{mol}----(7)
\end{aligned}
$$

Boudouard reaction:

$$
\mathrm{C}+\mathrm{CO}_{2} \leftrightarrow 2 \mathrm{CO} \quad \Delta \mathrm{H}=+172.6 \mathrm{KJ} / \mathrm{mol}----(8)
$$

Water gas reaction:

$$
\mathrm{C}+\mathrm{H}_{2} \mathrm{O} \leftrightarrow \mathrm{CO}+\mathrm{H}_{2} \quad \Delta \mathrm{H}=+131.4 \mathrm{KJ} / \mathrm{mol}--(9)
$$

Methanation reaction:

$$
\mathrm{C}+2 \mathrm{H}_{2} \leftrightarrow \mathrm{CH}_{4} \quad \Delta \mathrm{H}=-74.9 \mathrm{KJ} / \mathrm{mol}-----(10
$$

Water gas shift reaction:

$\mathrm{CO}+\mathrm{H}_{2} \mathrm{O} \leftrightarrow \mathrm{CO}_{2}+\mathrm{H}_{2}$

$$
\Delta H=-41.2 \mathrm{KJ} / \mathrm{mol}--(11
$$

Methane reforming reaction:

$$
\begin{array}{cc}
\mathrm{CH}_{4}+\mathrm{H}_{2} \mathrm{O} \leftrightarrow \mathrm{CO}+3 \mathrm{H}_{2} & \Delta \mathrm{H}=-206.3 \mathrm{KJ} / \mathrm{mol}(12) \\
\mathrm{CH}_{4}+2 \mathrm{H}_{2} \mathrm{O} \leftrightarrow \mathrm{CO}+4 \mathrm{H}_{2} & \Delta \mathrm{H}=-165 \mathrm{KJ} / \mathrm{mol}-(13)
\end{array}
$$

\section{Specifying Components:}

In any types of simulation in Aspen Plus after flow sheeting the process specifying the necessary component is important to go the next process. In this fixed bed gasifier simulation process all the components were specified properly. Table 1 lists the components modelled in the simulation. Because the uncertainty of exact formulas of biomass and ash, they were defined as nonconventional solid components. For these components, only enthalpy and density were calculated during the simulation. Aspen Plus includes special models for estimating both enthalpy and density for coal-derived materials. These models can be used to estimate biomass properties as well since biomass can be considered as coal-derived material.

Table 1: Detailed data of the components modelled in the simulation [1]

\begin{tabular}{|l|l|l|l|}
\hline Component & Type & Component name & Formula \\
\hline BIOMASS & Nonconventional & - & - \\
\hline ASH & Nonconventional & - & - \\
\hline $\mathrm{C}$ & Solid & Carbon-Graphite & $\mathrm{C}$ \\
\hline $\mathrm{H}_{2}$ & Conventional & Hydrogen & $\mathrm{H}_{2}$ \\
\hline $\mathrm{N}_{2}$ & Conventional & Nitrogen & $\mathrm{N}_{2}$ \\
\hline $\mathrm{O}_{2}$ & Conventional & Oxygen & $\mathrm{O}_{2}$ \\
\hline $\mathrm{Cl}_{2}$ & Conventional & Chlorine & $\mathrm{Cl}_{2}$ \\
\hline
\end{tabular}




\begin{tabular}{|l|l|l|l|}
\hline $\mathrm{CO}$ & Conventional & Carbon-Monoxide & $\mathrm{CO}$ \\
\hline $\mathrm{CO}_{2}$ & Conventional & Carbon-Dioxide & $\mathrm{CO}_{2}$ \\
\hline $\mathrm{H}_{2} \mathrm{O}$ & Conventional & Water & $\mathrm{H}_{2} \mathrm{O}$ \\
\hline $\mathrm{CH}_{4}$ & Conventional & Methane & $\mathrm{CH}_{4}$ \\
\hline $\mathrm{S}$ & Conventional & Sulfur & $\mathrm{S}$ \\
\hline $\mathrm{SO}_{2}$ & Conventional & Sulfur-Dioxide & $\mathrm{O}_{2} \mathrm{~S}$ \\
\hline $\mathrm{NH}_{3}$ & Conventional & Ammonia & $\mathrm{NH}_{3}$ \\
\hline $\mathrm{H} 2 \mathrm{~S}$ & Conventional & Hydrogen-Sulfide & $\mathrm{H}_{2} \mathrm{~S}$ \\
\hline $\mathrm{HCl}$ & Conventional & $\begin{array}{l}\text { Hydrogen- } \\
\text { Chloride }\end{array}$ & $\mathrm{HCl}$ \\
& & & \\
\hline
\end{tabular}

\section{Physical Property Method:}

For this fixed bed gasifier simulation process, Redlich-Kwong-Soave cubic equation of state with Boston-Mathias alpha function property method was selected as the global property method for this model. It has been used to estimate all physical properties of the conventional components in the gasification process. This property method is comparable to the Peng Robinson cubic equation of state with the Boston-Mathias alpha function (PR-BM) property method. RKS-BM is recommended for gas-processing, refinery and petrochemical applications such as gas plants, crude towers and ethylene plants. This method is generally used for nonpolar or mildly polar mixtures, like hydrocarbons and light gases such as CO2, hydrogen sulfide and H2. Using RKS-BM, reasonable results can be expected at all temperatures and pressures. The RKS-BM property method is consistent in the critical region. The enthalpy and density model selected for both feed and ash are nonconventional components, HCOALGEN and DCOALIGT. In this study, feed was defined as nonconventional components and the above model was selected during the simulation process.

\section{Specifying Feed stream:}

After renaming the stream in the simulation process, it is important to specify all the necessary input streams. In this simulation the biomass (coffee bean husk and rice husk) was specified as nonconventional stream and the ultimate and proximate analyses, given in Table 3.2 were entered. The biomass lower heating value $(L H V)$ was also specified with the HCOALGEN and DCOALIGT property models chosen to estimate the biomass enthalpy of formation, specific heat capacity and density based on the ultimate and proximate analyses. Finally, the stream thermodynamic condition (1bar and $25{ }^{\circ} \mathrm{C}$ ) and mass flow rate of $1.5 \mathrm{~kg} / \mathrm{hr}$ were used as an input for the process model.The detailed specifications for the inlet streams in this gasification process are listed in table 2 .

Table 2 : The specifications for the inlet streams in the process model

\begin{tabular}{|l|c|c|c|c|}
\hline Stream & Component & Pressure & Temperature & $\begin{array}{c}\text { Mass } \\
\text { flow } \\
\text { rate }\end{array}$ \\
\hline BIOMASS & $\begin{array}{c}\text { Specified as its } \\
\text { proximate, } \\
\text { ultimate and } \\
\text { sulfur analysis }\end{array}$ & 1 bar & $25^{0} \mathrm{C}$ & 1.5 \\
$\mathrm{Kg} / \mathrm{hr}$
\end{tabular}

\section{RESULTS AND DISCUSSION}

\section{Proximate and Ultimate analysis:}

In the gasifying process of any type of biomass, it is important to know the physical and chemical properties of the biomass feedstock used. The biomass, which is used for this study is coffee bean husk and the rice husk was also characterized. The determination is carried out duplication and the average values are to be taken and the result obtained 
is used for the simulation process of the fixed bed gasifier.

Table 3 : Proximate and Ultimate analysis of feed used in simulation

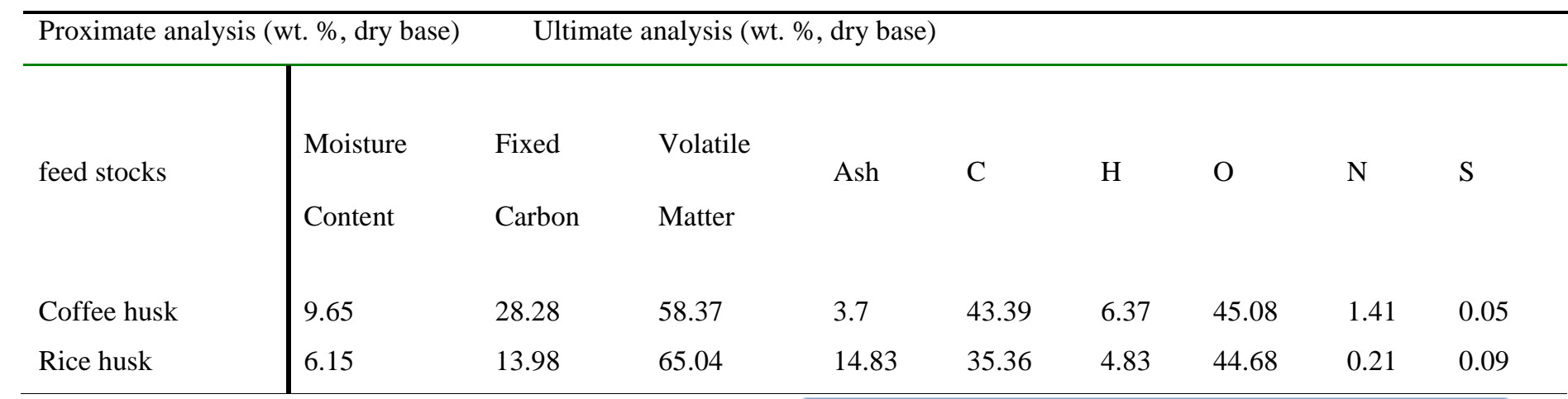

\section{Gasification Temperature:}

Gasification temperature is one of the most influential factors affecting the product gas composition and properties. The effect of gasifier temperature on producing syngas composition is shown in figure 1 . The temperature considered varies from $400^{\circ} \mathrm{C}$ to $1400^{\circ} \mathrm{C}$ when $1.5 \mathrm{~kg} / \mathrm{hr}$ of the biomass (coffee bean husk and rice husk) and 1 bar of pressure. The concentration of $\mathrm{CO}$ is increased with the increase of the gasification temperature while $\mathrm{CO}_{2}$ concentration followed an opposed manner. The $\mathrm{CH}_{4}$ concentration is also decreased as the gasification temperature increased. And $\mathrm{H}_{2}$ is rise with the increasing of gasifier temperature. The temperature of the gasifier is playing a great role in the production of $\mathrm{H}_{2}$ rich synthesis gas from biomass. As we examine from the following figure the hydrogen gas is increasing with increasing of temperature. These tendencies can be attributed to the chemical reaction laws; the higher temperature favoured the products in endothermic reactions, and favoured the reactants in exothermic reactions.

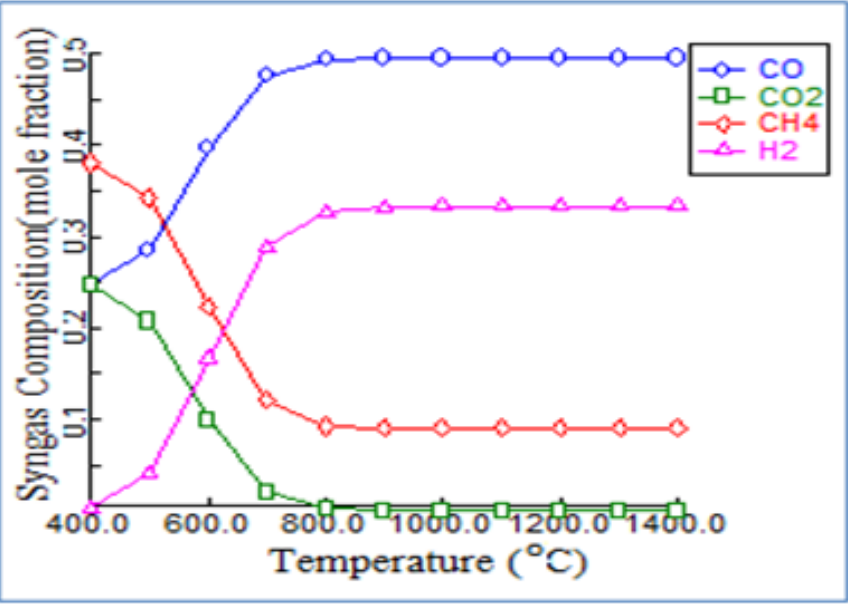

A

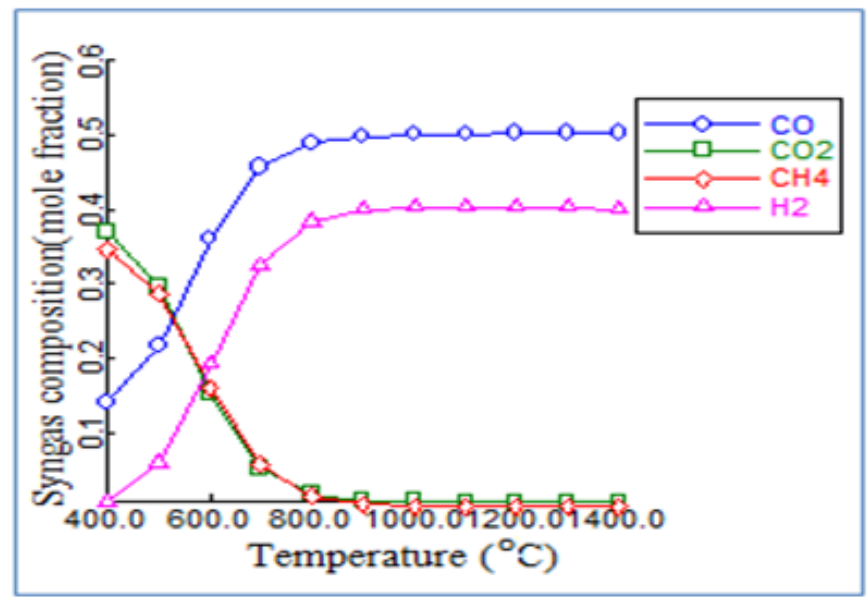

B

Figure $1:$ The effect of temperature on the syngas composition (A) for coffee bean husk and (B) for rice husk

\section{Gasification pressure:}


Pressure is also one of the most gasification factors which influence on the composition of syngas production. The effect of gasifier pressure on produced syngas composition is shown in figure 2 . The pressure considered varies from 1 to 10 bars. The result is examined by varying the pressure of the gasifier and making the other parameters kept constant. The amount of the concentration of $\mathrm{H}_{2}$ and $\mathrm{CO}$ is increased at lower pressure in case of the two biomass feed stocks but as the increasing of the gasification pressure the concentration of $\mathrm{CO}_{2}$ and $\mathrm{CH}_{4}$ is increased.

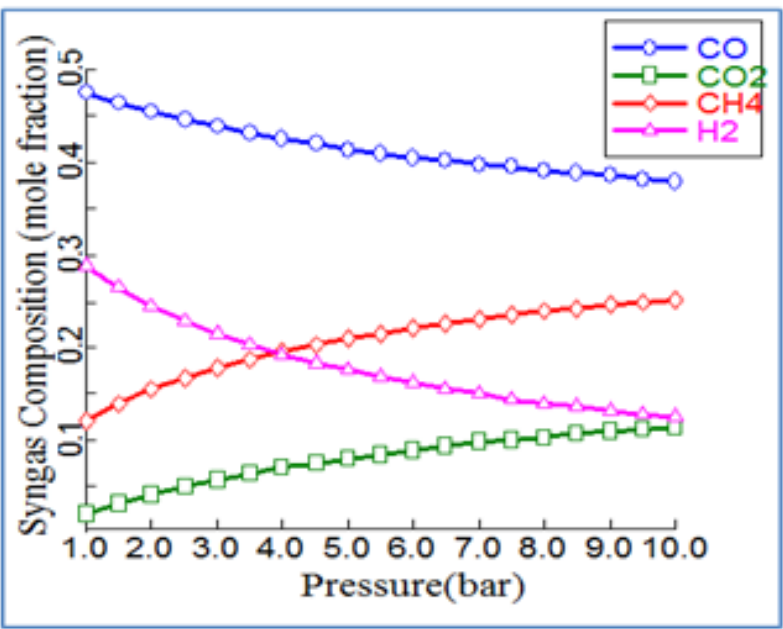

A

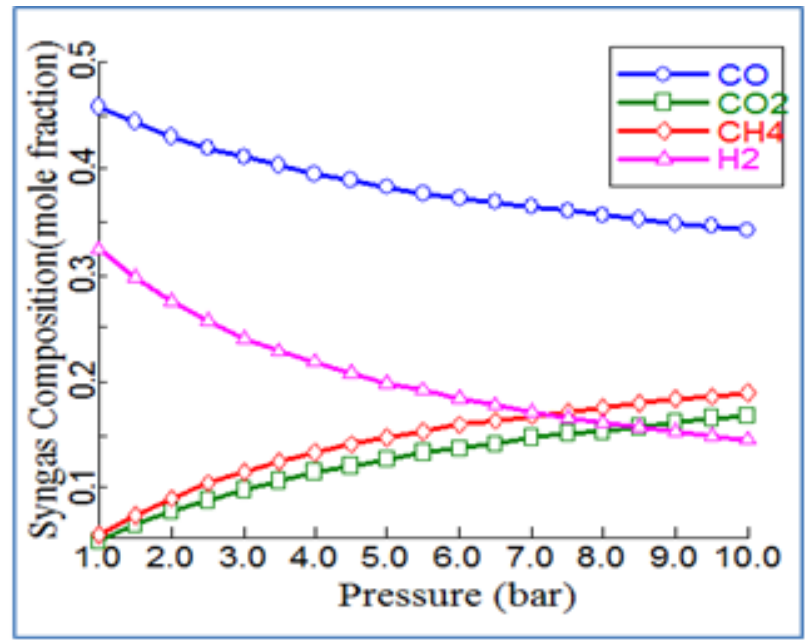

B

Figure 1: The effect of pressure in the syngas composition (A) for coffee bean husk and (B) for rice husk

\section{Equivalence Ratio, ER:}

In this gasifier simulation process, the effect of airbiomass ratio on the product gas composition was examined. The simulation results for the syngas composition versus air to biomass ratios covered a range of 0.2 to 1.0 the investigation was made at the value of biomass flow is fixed at $1.5 \mathrm{~kg} / \mathrm{hr}$ and air mass flow is ranged between 1.67 to $5 \mathrm{~kg} / \mathrm{hr}$ and the other gasification parameters are unchanged ( temperature and pressure). In figure 3 it is obvious that the production of both $\mathrm{H}_{2}$ and $\mathrm{CO}$ decrease with the increasing amount of air. Air to biomass ratio not only represents the $\mathrm{O}_{2}$ quantity introduced into the gasifier, but also affects the gasification temperature under the condition of auto thermal operation. Higher air to biomass rations can cause syngas quality to lower because of an increasing oxidation reaction. Alternatively, higher air to biomass ratio means a higher gasification temperature, which can accelerate the gasification and improve the product quality to a certain extent.

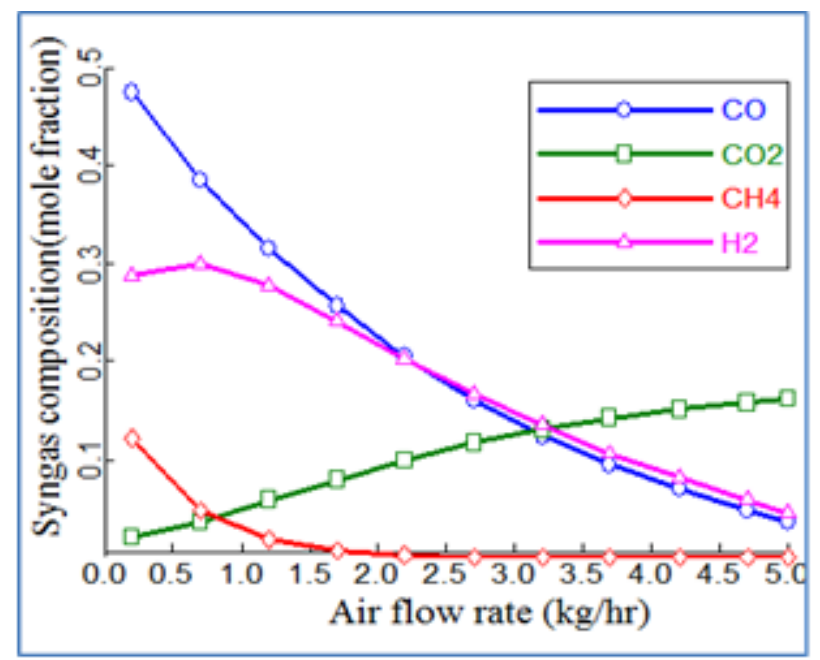

A 


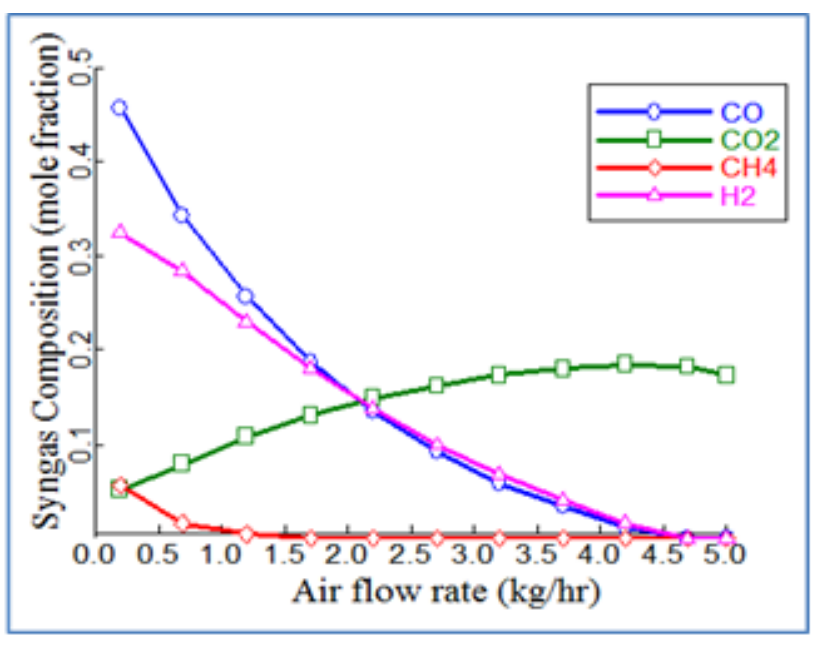

B

Figure 2: The effect of air flow rate on the syngas composition (A) for coffee bean husk and (B) for rice husk

\section{Biomass moisture content}

The moisture content of the biomass is another factor that affects the composition of syngas produced from gasification process. The effect of the biomass moisture content on the composition of syngas produced from the gasifier was examined by varying the moisture content from $5 \%$ to $35 \%$. The data obtained from the moisture content of the biomass were shown in figure 4 . As examined from the figure the amount of moisture content is increased the $\mathrm{H}_{2}$ and $\mathrm{CO}_{2}$ composition in the syngas is slightly increased and $\mathrm{CO}$ and $\mathrm{CH}_{4}$ composition in the syngas is decreased.

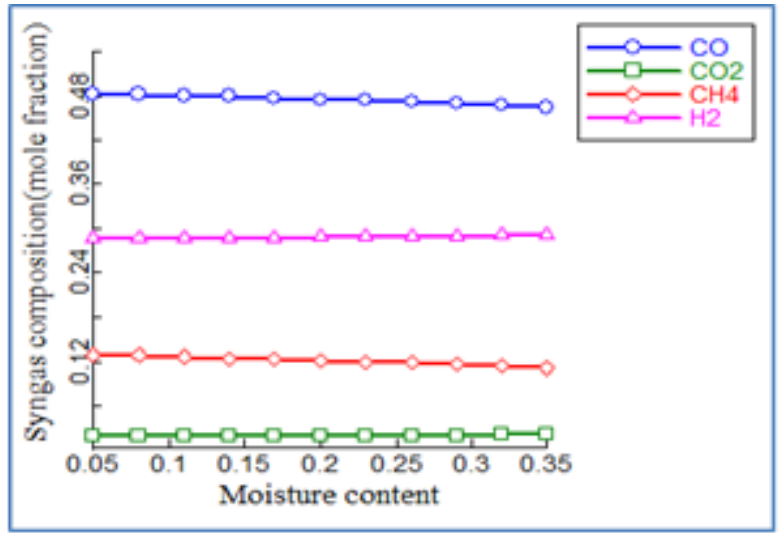

A

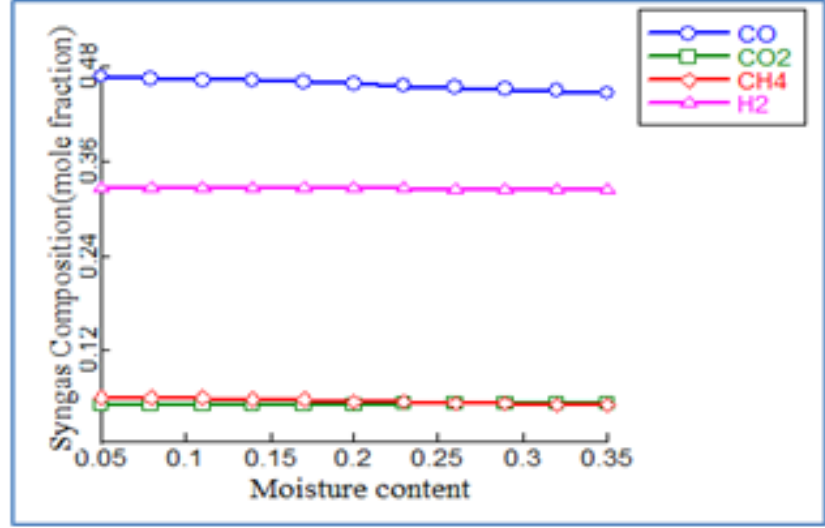

B

Figure Error! No text of specified style in document. :

The effect of biomass moisture content on the composition of syngas (A) for coffee bean husk and (B) for rice husk.

\section{Reactor volume:}

The reactor volume is also another factor in the produced syngas composition. As we examined from figure 5 increasing the reactor volume the composition of the $\mathrm{H}_{2}$ and $\mathrm{CO}$ amount increased for both biomass feed stocks. But the composition of $\mathrm{CO}_{2}$ and $\mathrm{CH}_{4}$ is produced in small amounts at a constant composition as the volume of the reactor increased.

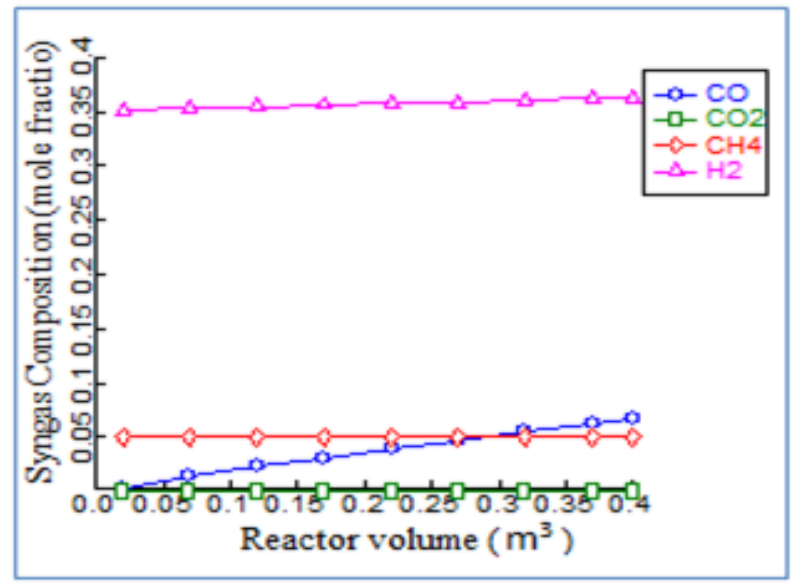

A 


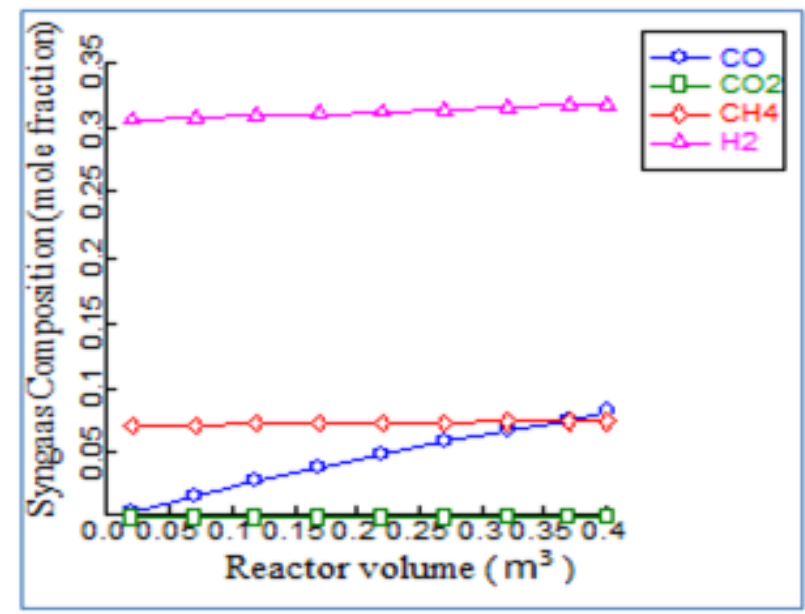

B

Figure 3 : The effect of reactor volume in the syngas composition (A) for coffee bean husk and (B) for rice husk

\section{Lower Heating value of produced gas (Syngas):}

The LHV of syngas depends on the other operating parameters of the gasifier. As the gas composition is affected by temperature, this also significantly affects the LHV of the produced gas. The best way to get a $\mathrm{LHV}$ as high as possible is to produce a gas enriched in $\mathrm{CO}, \mathrm{CH}_{4}$ and $\mathrm{H}_{2}$ which could be suitable for energetic exploitation for instance in internal combustion engines and turbines for the production of power. The LHV of the gas has been calculated using the following equation[11]

$$
\begin{gathered}
L H V=\left(10110 * X_{C O}+119494 * X_{H_{2}}+49915\right. \\
\left.* X_{C_{H_{4}}}\right) \mathrm{kJ} / \mathrm{kg}
\end{gathered}
$$

Where $X_{C O}, X_{\mathrm{H}_{2}}$ and $X_{\mathrm{CH}_{4}}$ are the mole fraction of producer gas. The Lower Heating Value of the producer gas are $\mathrm{LHV}_{C O}=10,110 \mathrm{~kJ} / \mathrm{kg}, \mathrm{LHV}_{\mathrm{CH} 4}=$ $49,915 \mathrm{~kJ} / \mathrm{kg}$ and $\mathrm{LHV} \mathrm{H}_{2}=11,949 \mathrm{~kJ} / \mathrm{kg}$ [12]. As we observe from figure 4.6 the increasing the temperature there is also increasing the heating value of the biomass feed stocks. The concentration of $\mathrm{H}_{2}$ whose coefficient within the above equation is the largest and this implies the increasing with temperature there is the increasing of $\mathrm{H}_{2}$ and $\mathrm{CO}_{2}$ concentration .At the lower concentration and the lower temperature the heating value is increased fast. After some time later both biomass heating value is increased slightly. Both biomasses have the reaches maximum heating value at the temperature of $800^{\circ} \mathrm{C}$ and as the temperature increase the heating value are increases slightly. As inspected from the following figure the rice husk has heating value of $51,542.12 \mathrm{~kJ} / \mathrm{kg}$ and the coffee bean husk has $48,773.85 \mathrm{~kJ} / \mathrm{kg}$.

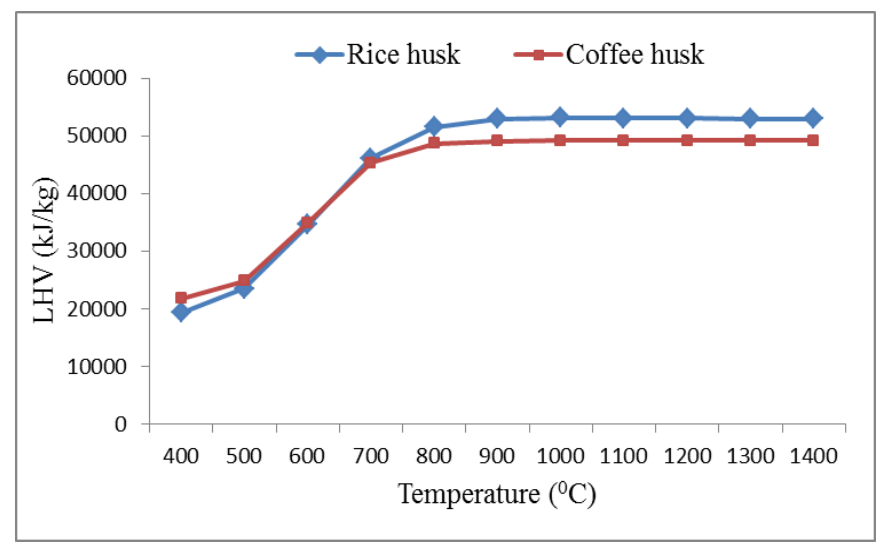

Figure 4 : The effects of temperature on the heating value of syngas

increase in a gasification pressure the methane concentration is also increasing and the result implies that the LHV of the syngas decreased as shown in figure 7 . The heating values of the biomass have been reaching a maximum at the lower pressure and decrease as the increasing of the pressure.

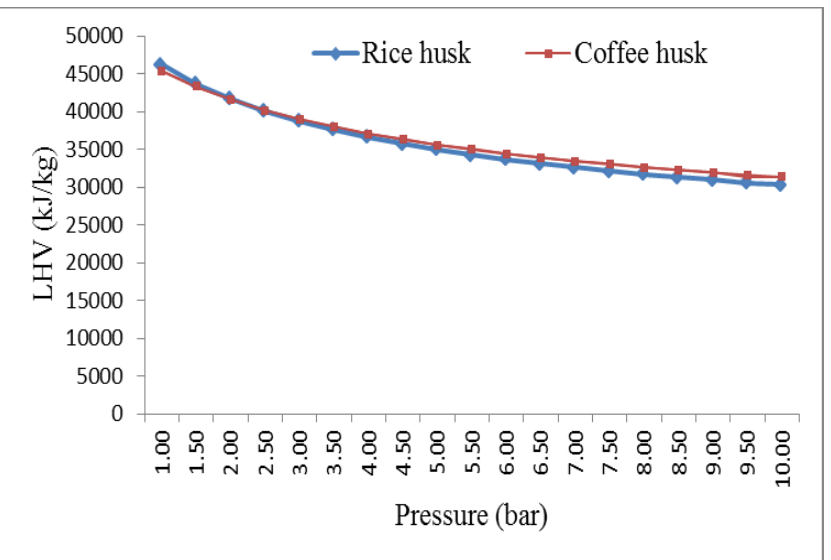

Figure 5: The effect of pressure on the heating value of syngas 


\section{IV.CONCLUSION}

The simulation was used to predict the results of biomass gasification, and to provide some process fundamentals about syngas production from the biomass gasification. The effects of gasification temperature, air equivalence ratio and moisture content concentration on the composition of syngas, lower heating value of syngas. The higher gasification temperature increased the lower heating value, the heat conversion efficiency and carbon conversion. The effective temperature of gasifier for the production of syngas should be $800^{\circ} \mathrm{C}$ at the air equivalent ratio of 0.2 .The increasing of the moisture content is decreasing the heating value of the produced syngas produced from the gasification of biomass.

\section{REFERENCES}

[1]. Ke, S., Optimization of biomass gasification reactor using Aspen Plus in Faculty of Technology 2014, Telemark University College Norway. p. 76.

[2]. Emma Barker Hemings, et al., Detailed Kinetics of the Pyrolysis and Oxidation of Anisole. 2010, Politecnico di Milano P.zza Leonardo da Vinci 32,: Milano, Italy.

[3]. Buljit Buragohain, et al., Comparative evaluation of kinetic, equilibrium and semi-equilibrium models for biomass gasification. International Journal of Energy and Environment, 2013. 4(4): p. 581-614.

[4]. Chittaranjan, P., Aspen Plus Simulation And Experimental Studies on Biomass Gasification, in Chemical Engineering. 2012, National Institute of Technology Rourkela. p. 39

[5]. Schuster G., G.L., Weigl K. , Hofbauer H., Biomass steam gasification an extensive parametric modeling study. Bioresource Technology, 2001.

[6]. Cornelius E. Agu, R.K.T. and Britt M. Halvorsen, Simulation of Simplified Model for Kinetics of Biomass Gasification. 2015, Telemark University College,: Norway.
[7]. Sharma, A.K., Equilibrium and kinetic modeling of char reduction reactions in a downdraft biomass gasifier. A comparison.Solar Energy 2008. 82: p. 918-28.

[8]. Chen Chong, Y.J.-h. J.Y.-q., and C. Yong, Simulation of municipal solid waste gasification for syngas production in fixed bed reactors. Journal of Zhejiang University-Science and Applied Physics \& Engineering, 2010. 11(8): p. 619-628.

[9]. Process modelling tool for conceptual design, optimization, and performance monitoring of chemical processes [Internet]. Aspen Technology, Inc.

[10]. Zheng, L.F., and E, Aspen simulation of cogeneration plants. Energy Conversion and Management, 2003. 44: p. 1845-51.

[11]. Lv P.M., X.H., Chang J., Wu C.Z., Chen Y., Zhu J.X. , An experimental study on biomass airsteam gasification in a fluidized bed. Bioresource Technology, 2004. 95: p. 95-101.

[12]. Lars Waldheim and Torbjorn Nilsson Heating Value of Gases from Biomass Gasification Report prepared for. 2001, Task 20 - Thermal Gasification of Biomass IEA Bioenergy Agreement.

[13]. Wurzenberger, J.C., Wallner S., and Raupenstrauch H., Thermal conversion of biomass. comprehensive reactor and particle modelling. AIChE Journal, 2002. 48(10): p. 2398-411.

[14]. Nikoo M. B. and Nader M., Simulation of biomass gasification in fluidized bed reactor using ASPEN PLUS. Biomass and Bioenergy, 2008. 32: p. 1245-54.

[15]. Rapagna S., J.N., Kiennemann A., and Foscolo P. U., Steam gasification of biomass in a fluidized bed of olivine particles. Biomass and Bioenergy, 2000. 19: p. 187-97.

[16]. Franco C., P.F., Gulyurtlu I., and Cabrita I., The study of reactions influencing the biomass steam gasification process. Fuel, 2003. 82: p. 835-42.

[17]. Kuo, P.C., Wu, W. ,Chen, W. H, Gasification performances of raw and torrefied biomass in a downdraft fixed bed gasifier using thermodynamic analysis. Fuel, 2013. 117: p. 1231-41. 
[18]. Chen, C., Jin, Y.Q., Yan, J.H., Chi, Y, Simulation of municipal solid waste gasification in two different types of fixed bed reactors. fuel, 2013. 103: p. 58-63.

[19]. R.S. Boone and E.M. Wengert, Guide for Using the Oven-Dry Method for Determining the Moisture Content of Wood 1998, University of WISCONSN-MADISON.

[20]. Sun L, Chemical Engineering Process Simulation using Aspen Plus. Chemical Industry Press 2012.: p. 326.

[21]. Process modelling tool for conceptual design, optimization, and performance monitoring of chemical processes [Internet]. Aspen Technology, Inc.

[22]. Zheng, L.F., and E, Aspen simulation of cogeneration plants. Energy Conversion and Management, 2003. 44: p. 1845-51. 